\title{
Ode to a Sailor DONNACARNES
}

sailor,

fleeting mood image of you;

all sailor in bear grace,

rough hands and poetic dream;

etched in sunlight at land's end;

teacher in the rough most elegant and simple.

sailor,

you draw me like moon pull;

you don't know how alike you are,

you, the sea, and the force of wild wind;

so like the sun, the comfort warmth of you;

I will miss you all the days of my life.

\section{THE LOSS}

Jim Gray went missing without a trace on January 28, 2007, whilst sailing solo to the Farallon Islands on our sailboat Tenacious to put to rest the ashes of his mother, Ann (see Silberman, S. Where is Jim Gray? 2007. Wired Magazine 15(08): 130-139, 154-155). Jim is a beloved father, grandfather, and brother. Jim is my husband, my sweetheart, my companion in adventure, and my Tolkien soulmate. To the family, Jim was in many ways larger than life, and he was always there for us, despite the dense hours he spent beavering away as a brilliant scientist. He had a compelling and seasoned love of the wild sea and mountains. In the many adventures we shared with him, although he sometimes took the path less traveled, we thought him to be bulletproof. We are desolate in our loss of Jim, even as we strive to live as fully as he did. We remain in awe of the efforts Jim's friends and colleagues have made searching for him, and we are greatly honored by, and find sweet solace in, the tributes friends and colleagues are paying to our lost golden boy. 


\section{THE SEARCH}

Much has happened since that winter's day when Jim and Tenacious did not come home, the day that changed the lives of this family forever. Friends, family, colleagues, and professional groups intensively and methodically searched for Jim above water for almost three weeks. The Coast Guard initiated an immediate, excellent, and comprehensive search for him. I cannot thank the Coast Guard enough for its ongoing efforts to try and find Jim and Tenacious, and for the comfort they offered me, especially during that first long night-the night only a few of us knew Jim was missing, the night when we still had high hopes that he was just overdue. The Coast Guard's professional search was complemented by the Friends of Jim search, which Mike Olson succinctly and eloquently summarizes in his article titled "The Amateur Search." Mike acknowledges the extended amateur search team and identifies some of the key players; I would also like to acknowledge the tremendous effort Mike made in helping us with many aspects of the search and its aftermath. I wish to reiterate our family's gratefulness to all of the searchers, some of whom I worked with closely (those experiences are diamond-etched in my mind forever) and some of whom I have never met. I don't know the names of the many people who reviewed the Amazon Turk satellite tiles, but to every single searcher I wish to say: your actions are such a positive offset to the loss of Jim. You worked so hard to find Jim. We will always remember the goodness of what you did. Jim was a very lucky man, and we are a very fortunate family, to have so many people care enough to search so hard for him.

When we couldn't find Jim above water, we searched the seafloor for $3 \frac{1}{2}$ months. The underwater search is chronicled in the article written by Ed Saade: "Search Survey for $S / V$ Tenacious: Gulf of Farallones and Approaches to San Francisco." I wish to thank Ed and his team of professionals for the high quality and thoroughness of their search, and for the kindness and grace they extended to me during the search. I also wish to thank Bob Bilger (an independent marine search expert) for his dedicated effort to locate Tenacious. To the many others who helped with the underwater search, I extend the deeply felt thanks of the family. Most of all, I want to thank Paula Hawthorn for all the help and comfort she has offered during this past year, and especially for staying with me during the whole course of the underwater search. Paula, I think Jim would say that I owe you about a zillion bottles of Ridge Zinfandel (and I'm working on that). But mostly, I want you to know what a positive difference you made, as you freely partook of this journey through the slow-moving, distorted time warp of searching under water.

\section{ADRIFT}

Dr. Pauline Boss, an expert on ambiguous loss, indicates that it is the loved ones left behind who can become adrift when "a death requires a presumption" (see Silberman, S. 2007. "Where is Jim Gray?" Wired Magazine 15(08): 155). Pauline writes of the nature and consequences of Jim's ambiguous loss in her article, "A Tribute Not a Memorial: Understanding Ambiguous Loss." Certainly the months immediately following the end of the underwater search felt like No Man's Land to me. When we couldn't find Jim above or below water (and, yes, the Pacific is a rather large and wild ocean), when the underwater search ended on May 31, 2007, it was a very sad day, for we had by then lost two opposing hopes. We had first hoped to find Jim alive during the above-water search. Failing that, we hoped to find out what had happened to Jim by searching the seafloor 
between the Farallones and the area north of the Golden Gate Bridge (Jim's most likely path home). Each day of the underwater search, I looked for what I dreaded to find: Tenacious lying on the seabed. Initially, I was relieved at the end of each day that we had not found Tenacious. As time passed, however, I realized that we truly might lose our second hope, our hope of finding Tenacious, and our hope of ever knowing what happened to Jim and where it happened. But we lost that hope as well, for even after searching more than 300 square nautical miles of seabed, we did not find a trace of Tenacious.

So we all paused for a while; certainly the family was just exhausted by the end of May. Jim's absence, the hurly-burly of the publicity surrounding the above-water search, the duration of the underwater search, and the ambiguity of it all took an enormous toll on the family and close friends.

\section{TRANSITIONS}

By late September, however, people came together to organize a public tribute to Jim. Jim completed his undergraduate and Ph.D. studies at the University of California, Berkeley, and he often told me: "Berkeley made me, and I owe them a lot." Because of this, his public tribute is being held at his alma mater. Jim's friends, colleagues, and family are honoring him with the same intensity they used to search for him. That is what these proceedings are all about: paying tribute to Jim's work and Jim as an individual. We may never know exactly what happened to him that day at sea, but we do know the person he was and the quality of his mind and work. Within the family, we think of Jim as a beloved family member, as our Jim. We are also proud of his accomplishments as a famous scientist and a Turing Award winner. We understand that while he has filled up much of our worlds, his world is larger than us, even as we understand how important we were to him. But, in fact, in the eyes of his peers, Jim was much more than just a famous Turing Award winner, as the articles within these proceedings show. He was a man with a brilliant mind who connected deeply and productively with many co-workers over many decades. More than anything, he was a strong individual who built close relationships whilst doing his science; for certainly the relationships were key to the collaborative scientific research that he engaged in, research that is described in the articles written for the proceedings of the public tribute (http://www.eecs.berkeley.edu/IPRO/ JimGrayTribute/).

\section{PROCEEDINGS OF THE IIM GRAY TRIBUTE}

Several articles in the proceedings address Jim's accomplishments since his days at Berkeley. They are written by individuals, who, to a person, had long and close relationships with Jim. Michael Harrison has known Jim since his undergraduate days and writes of Jim's accomplishments at Berkeley ("Jim Gray at Berkeley"). Pat Helland, Jim's friend and peer for more than 25 years, discusses Jim's role as a friend and peer mentor in his article "Knowledge and Wisdom." Ed Lazowska, also a friend and peer of Jim's for more than 25 years, writes about Jim's academic mentoring in his article "500 Special Relationships: Jim as a Mentor to Faculty and Students." Mike Stonebraker, Jim's friend and peer, summarizes Jim's contributions in the field of computer science in his article: "Why Did Jim Gray Win the Turing Award?" Your karma is good, Mike, and I thank you for all that you have done for Jim and for me.

David Vaskevitch and Rick Rashid, co-workers and friends of Jim's at Microsoft, write 
of his contributions to industry and of his special ability not only to communicate with others, but also to foster communications amongst diverse groups and disciplines, including areas outside the traditional realm of computer science (Vaskevitch, "Jim Gray: His Contribution to Industry"; Rashid, "A Gap Bridger").

Bruce Lindsay, our longtime sailing and backpacking buddy, who has known Jim since his Berkeley days, discusses Jim's contributions to transaction-processing concepts and techniques ("Jim Gray at IBM: The Transaction Processing Revolution"). Jim's Tandem years are covered by his old friends and peers, John Nauman and Wendy Bartlett ("Jim Gray's Tandem Contributions"). Dave DeWitt and Charles Levine overview Jim's role in the specification of the debit/credit benchmark ("Not Just Correct, but Correct and Fast: A Look at One of Jim Gray's Contributions to Database System Performance"). David and Jim collaborated for many decades, and Jim visited the University of Wisconsin-Madison yearly. David has just become director of the new Microsoft Jim Gray Systems Lab in downtown Madison, Wisconsin. Jim had worked hard to help make this lab happen and would say it is "Great!" that it now exists.

Gordon Bell writes about Jim's impact in building indefinitely scalable tools ("Scalability and Immortality"). I occasionally watched Gordon and Jim at work together in their unique, mad-scientist, creative-process mode, which sometimes involved experimentation in which the odd piece of hardware or software blew up. To my eyes, they were bonded like two boy scouts, and I watched their world of discovery and invention with great delight.

Andreas Reuter tells the tale of writing the Transaction Processing book in his article "Is There Life Outside Transactions? Writing the Transaction Processing Book." Jim talks about the start of this book in one of his letters written to me in 1987: "I bought a Mac to write the Great American Technical Novel. I was to start March 16, but now it is April 27 th and I have yet to do anything on it.... So in June I'll take a leave of absence from Tandem and devote myself to writing. I will take about three months to start, I figure. It will be lonely and I am scared that the book may not be good in the end.... I hope that the book is good. It's a big risk to sink that much ego into something, a big decision for me." As Andreas will tell you, the book took a little longer than expected to finish, but many good adventures and lots of fine wine and food were had in the process. Tom Barclay, Jim's peer of many years, writes of another adventure and collaborative effort in his article "TerraServer and the Russian Adventure...." During this collaboration, Tom and Jim went to Russia in the dead of winter to obtain access to Russian satellite imagery, and in the process, Jim learned a little more about Russian toasts, as well as deep winter.

Jim's accomplishments in recent years are discussed in the concluding articles: "The Sloan Digital Sky Survey and Beyond" (Alex Szalay), "Building the WorldWide Telescope" (Curtis Wong), and "Exploring Ocean Data" (James G. Bellingham). Alex and Jim had a special relationship, and yes, Alex, Jim would be honored and amazed that you might even think to name an asteroid after him. Curtis, you already know how blissed out Jim would be over the success of the WorldWide Telescope, and he would be so honored that you dedicated it to him. Jim Bellingham started working with Jim in 2004 and was extraordinarily helpful in doing drift analysis during the search for Jim. Taken as a whole, the detailed e-mail communication between Jim Gray and Jim Bellingham is a fine example of how relationships nurture the genesis, application, and success of collaborative research. 


\section{THE ROAD GOES EVER ON AND ON}

Jim did say to me several times over the years, "First you live and then you die," but we never even thought about what happens when you vanish without a trace. Jim was an avid Tolkien fan, and I believe that he would agree with Tolkien's lyrical words about the ambiguity of life, expressed in this Old Hobbit Walking Song (Tolkien, J.R.R. 1974. The Return of the King. Lord of the Rings, Collector's Edition. Boston: Houghton Mifflin: 308):

Still round the corner there may wait A new road or a secret gate; And though I oft have passed them by, A day will come at last when I Shall take the hidden paths that run West of the Moon, East of the Sun.

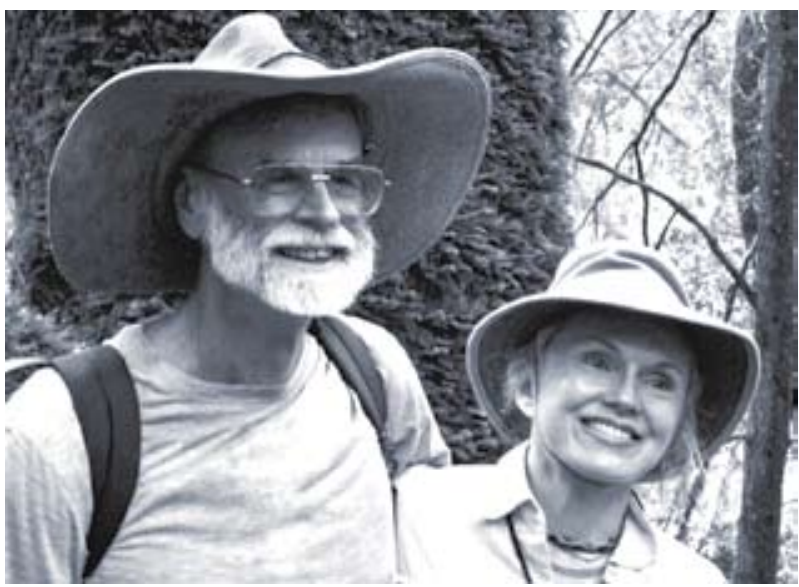

